\title{
Effect of storage conditions and sodium hypochlorite treatment on germination of Cucumis prophetarum (Cucurbitaceae) seeds from arid Arabian deserts
}

Hatem Ahmed Shabana ( $\square$ hatem_shabana@sra.ae)

Sharjah Research Academy https://orcid.org/0000-0002-1687-0938

Tamer Mahmoud

Sharjah Research Academy

Sanjay Gairola

Sharjah Research Academy

Asma Al Ketbi

Sharjah Research Academy

Mariam Aljasmi

Sharjah Research Academy

Mariam Al Sallani

Sharjah Research Academy

Research article

Keywords: Cucurbitaceae, Cucumis prophetarum, Germination requirements, $\mathrm{NaOCl}$, orthodox seeds, sterilization, storage conditions

Posted Date: February 10th, 2021

DOI: https://doi.org/10.21203/rs.3.rs-201765/v1

License: (c) (i) This work is licensed under a Creative Commons Attribution 4.0 International License. Read Full License 


\section{Abstract \\ Background}

This is the first study on seed germination of Cucumis prophetarum in the Arabian Peninsula. Light and temperature as the main environmental factors and seed storage conditions greatly affect the germination of many Cucurbitaceae species. C. prophetarum is the perennial prostrate with woody rootstocks that grow throughout the year in the arid Arabian deserts. We examined the effects of seed storage conditions and sterilization by sodium hypochlorite ( $\mathrm{NaOCL}$ ) on germination of $C$. prophetarum seeds. Matured, fresh and field stored seeds were collected in March of 2016 and 2017 from a population in the United Arab Emirates. Fresh and the stored seeds (field, freeze, and room temperature) were germinated at three temperature regimes $\left(15 / 25,20 / 30\right.$ and $\left.25 / 35^{\circ} \mathrm{C}\right)$ in both continuous darkness and alternating $12 \mathrm{~h}$ light $/ 12 \mathrm{~h}$ darkness.

\section{Results}

The fresh and freeze stored seeds had higher germination percentage than the field and room temperature stored seeds. High germination was recorded in both lower and moderate temperatures $\left(15 / 25\right.$ and $\left.20 / 30^{\circ} \mathrm{C}\right)$ in light conditions. Sterilization of the seeds by $\mathrm{NaOCl}$ had a negative effect on the speed and germination percentage under all storage conditions, and it changes light and temperature requirements of seeds for germination.

\section{Conclusions}

Germination of $C$. prophetarum is sensitive to incubation light and temperature as well as to the seed storage conditions. The germination ability of stored seeds indicates that seed storage behaviour of $\mathrm{C}$. prophetarum is orthodox. Light and temperature requirements for seed germination reflects a suitable place, habitat, and time for seedling emergence of $C$. prophetarum. The effect of $\mathrm{NaOCl}$ treatment on the germination may be associated with concentration and exposure periods of seeds. Therefore, we suggest that when using $\mathrm{NaOCl}$ for seed sterilization or to stimulate the germination, caution must be taken for using its concentration and exposure time, especially for species with thin and soft seed coats like $C$. prophetarum. Further studies on seed germination ecology would help to understand better the adaptive strategy of the $C$. prophetarum in the arid desert environments.

\section{Background}

Plant seeds usually experience varying environmental conditions during development and maturation in natural habitats, and their storage under different conditions can influence dormancy, germination, and seedling emergence $[1,2,3,4,5,6]$. The seeds are generally categorized according to the post-shedding storage characteristics to orthodox, intermediate, and recalcitrant. The storage behavior is the capacity of 
seeds to survive desiccation $[7,8,9,10]$. Orthodoxy and recalcitrance are the extremes categories. Orthodox seeds are desiccation-tolerant and can survive low moisture content (ca., $5 \%$ or below). As such, seeds are not chilling sensitive, they can be stored over the long-term at $-20^{\circ} \mathrm{C}$ and dry condition without significant viability loss. In contrast, recalcitrant seeds need water to survive (i.e., they are damaged by desiccation), are mostly short-lived and can be stored for a few months. Intermediate seeds lie between the previous categories that seeds can tolerate drying to about $7-11 \%$ moisture content and lose viability more rapidly at low temperature $[11,8,9,12]$.

The wild plant species have plasticity traits and strategies to respond to environmental variations and survive harsh conditions [13]. One important strategy is dormancy, that is the inability of a viable seed to complete its germination under favorable conditions in which non-dormant seeds germinate. Dormancy is critical for enabling seeds to delay their germination until the environment becomes favorable to seedling survival $[14,4]$. Literature suggests that the mature seeds of the majority of wild species possess varying degrees of dormancy, which enables the distribution of germination over time and hence determines the survival of a species and its populations in variable environments $[14,15]$. For example, in the desert regions with long, dry, and hot summers, the seed dormancy is an important survival strategy that prevents seed germination after seed maturation until the rainy season. In general, seed dormancy is controlled by some environmental factors, such as temperature, light, and seed storage conditions $[16,6]$.

Temperature and light are considered important environmental factors that regulate seed germination, ecological interaction and can influence species distribution $[17,6,18]$. Temperature is the main determinant in seed germination of many species and each species has an optimal temperature for its seed germination. Likewise, a light requirement of seed germination is variable as seeds of many species require light for germination. In contrast, others are insensitive to light, and in some species, the germination is inhibited by light $[19,20]$.

Storage conditions and duration are important factors affecting germination parameters. Bradychory or delayed dispersal is a mechanism through which plants retain their seeds within maternal plants until they are released $[21,22,23]$. Bradychory is described in many arid desert species where seed release from the mother plants is delayed until the occurrence of favorable conditions for seed germination and seedling establishment [24, 25, 26, 27]. Various environmental factors, such as temperature, light, and seed moisture contents, can control seed longevity under field storage conditions. Because of significant relationships between seed viability and the storage environment $[28,29]$, seeds stored under different conditions can produce a variety of seed germination patterns, ranging from zero to 100 percent germination $[30,20,6]$. Moreover, the longevity of seeds stored under laboratory conditions does not necessarily relate to their persistence in nature [31, 9], and therefore marked differences may occur.

The seed surface sterilization of many species is necessary to eliminate all microorganisms such as bacteria and fungi that can easily grow in vitro conditions during seed germination and may cause seed rot and reduction of germination percentage [32,33,34]. Sodium hypochlorite $(\mathrm{NaOCl})$ is an effective seed disinfectant against a variety of microorganisms like bacteria, viruses, and fungi; hence it is widely 
used as a sterilizing of seeds before germination experiments [35, 36, 34]. In general, to eliminate seedborne fungi and bacteria, seeds are soaked for several minutes in $0.5-5 \%$ of $\mathrm{NaOCl}$ and then washed several times in distilled water [35].

It has been documented that pretreatment of seeds by $\mathrm{NaOCl}$ can influence the seed germination and dormancy of many species. $\mathrm{NaOCl}$ can enhance germination for some species, such as Amaranthus powellii S. Wats [37], Polygonum convolvulus L. and Saponaria vaccaria L. [38], Stipa viridula Trin. [39], Angelica glauca Endgew. and Aconitum heterophyllum Wall. [40]. $\mathrm{NaOCl}$, also inhibited seed germination of some species like Brassica chinensis L. [41], while it had no effect on germination of other species such as Setaria faberi R.A.W.Herrm. and Abutilon theophrasti Medik. [37, 42].

The Cucurbitaceae family comprises approximately 1000 species, including numerous fruit crops and vegetables worldwide, and has significant economic importance [43]. Wild species of Cucurbitaceae have rich genetic diversity, which can help them adapt to different environmental conditions. Species of this family are mainly distributed in tropical and subtropical areas $[44,45,46]$.

Cucumis prophetarum $L$ (Cucurbitaceae) is a perennial desert plant with woody rootstocks and prostrate hairy stems that can reach up to $200 \mathrm{~cm}$ in length. Green with soft spines are immature fruits, while the mature ones are yellow. This species has many medicinal benefits against different ailments, including diabetes and diarrhoeic diseases, and used in traditional Indian medicine $[47,48]$. In the United Arab Emirates (UAE), C. prophetarum is uncommon and distributed mostly in mountain and wadi beds habitats. The flowering period of this plant is February to July $[49,50]$. C. prophetarum is bradychoric that can retain the mature seeds within the maternal canopy for varying periods [23]. Its diaspore unit is the seed (ca., $0.4 \mathrm{~cm}$ ) with ballistic dispersal mode as the seeds are forcefully ejected by explosive dehiscence of the fruit $[51,52,23]$.

Several studies have reported the role of light and temperature during the germination process of many Cucurbitaceae species. For the light condition, darkness is the main requirement for seed germination of many species such as Citrullus colocynthis (L.) Schrad. [4] Citrullus lanatus (Thunb.) Matsum. \& Nakai [53]. Seed germination of several species is sensitive to the temperature; for example, melon germination declined from almost $100 \%$ to zero when the temperatures were below the optimum (ca., 14 to $45^{\circ} \mathrm{C}$ ) [54]. C. colocynthis seeds had good germination in moderate and high temperatures $\left(20 / 30\right.$ and $\left.25 / 35^{\circ} \mathrm{C}\right)$, but no germination happened at $15 / 25^{\circ} \mathrm{C}$ in the light [4].

In general, few studies dealt with $C$. prophetarum germination traits. As per our review of available literature, no studies exist about seed germination of $C$. prophetarum in the Arabian Peninsula. Keeping this in view, the aim of this study was to investigate the effects of storage conditions (e.g., fresh seeds, room temperature, freezing, and field conditions) and sterilization of seeds by $\mathrm{NaOCl}$ on germination of $C$. prophetarum under different combinations of temperature and light conditions.

\section{Methods}




\section{Study area}

The United Arab Emirates lies in the south-eastern Arabian Peninsula between latitudes $22^{\circ} 40^{\prime}$ and $26^{\circ}$ $00^{\prime}$ north and longitudes $51^{\circ} 00^{\prime}$ and $56^{\circ} 00^{\prime}$ east. The climate of the country is hyper-arid, hot with two main seasons. A short rainy season from November to March, with mild temperatures around $20^{\circ} \mathrm{C}$ and a long dry, hot season with a mean temperature range between $35-40^{\circ} \mathrm{C}$ that can reach $47^{\circ} \mathrm{C}$ and humidity levels reaching more than $90 \%$. The rainfall is very scarce and erratic and concentrated from November to February $[81,82,83]$.

\section{Seed collection and storage treatments}

In March 2016, the yellow fruits of $C$. prophetarum, which had freshly mature seeds, were collected from a wild population in Al Shuwaib area (E: 24.781625, N: 55.817591 , alt: $241 \mathrm{~m}$ above sea level) of Abu Dhabi emirate, UAE. Identification of the plant was made by Hatem A. Shabana, Tamer Mahmoud, Sanjay Gairola at the SSBH and confirmed by using the relevant regional flora. The voucher specimens (SSBH 1237 \& SSBH 1255) were deposited in the herbarium of SSBH, Sharjah, UAE. In this study, all seeds were collected under international standard seed bank guidelines for scientific research and did not involve endangered or protected species. The permission was not needed to collect such samples for research purposes.

Generally, the yellow color is an indicator of fruit ripening in this species. The fruits were randomly collected from 20-25 individuals to diminish the effect of genetic variation within the population and the middle of the population to avoid the edge effect. These individuals were tagged permanently for future fruit/seed collection. Also, old fruits from these tagged plants were removed to ensure that the seed age was around one year at the next collection in March 2017. To assess the effect of field storage of seeds on germination, old fruits from the tagged individuals were collected after 12 months in March 2017.

Immediately after collection, the fruits were transported to the laboratory and seeds were extracted manually from the fruits, washed with water, and dried on a laboratory bench. The fresh seeds of March 2016 collection were divided into three parts; one part was germinated immediately after collection (hereafter referred to as fresh seeds), the second part was stored in brown paper bags at room temperatures $\left(20 \pm 2^{\circ} \mathrm{C}\right.$, hereafter referred as room temperature storage) and the third part was dried to $5-8 \%$ moisture content at $15{ }^{\circ} \mathrm{C}$ and $15 \%$ relative humidity followed by storage at $-18{ }^{\circ} \mathrm{C}$ (hereafter referred as freezing storage). Both second and third parts were stored for one year until their germination in March 2017. Seeds of March 2017 collection that remained in the field for about one year in the range of temperature between $16^{\circ} \mathrm{C}$ to $46^{\circ} \mathrm{C}$ (hereafter referred to as field storage) were immediately subjected to germination after collection.

\section{Seed sterilization and germination experiment}

Seeds of different storage conditions were divided into two groups prior to the starting of the germination experiment. The first group of seeds were disinfected with $50 \%$ Clorox solution (commercial bleach) 
containing 5.25\% Sodium hypochlorite for two minutes and rinsed several times in distilled water, while the second group was kept without sterilization.

Fresh (March 2016) and stored seeds (room temperature, freezing, field storage March 2017) were germinated in three programmed incubators set at daily night/day temperature regimes of $15 / 25^{\circ} \mathrm{C}$, $20 / 30^{\circ} \mathrm{C}$ and $25 / 35^{\circ} \mathrm{C}$ in both alternating $12 \mathrm{~h}$ light / $12 \mathrm{~h}$ darkness and continuous darkness. The light period coincided with the higher temperature. Three replicate Petri dishes were used for each treatment, each with 25 seeds. The germination was conducted in 9-cm diameter plastic Petri dishes containing one disk of Whatman No. 1 filter paper, with $10 \mathrm{ml}$ distilled water. During dark treatment, the Petri dishes were wrapped in aluminum foil to prevent light exposure before being placed in incubators. Seeds were considered to be germinated with the emergence of the radicals. Germinated seedlings were counted and removed every alternate day for 24 days following seed sowing. Seeds incubated in the dark were counted one time after 24 days because they were not exposed to any light during the incubation period.

\section{Data analyses}

The germination speed was assessed by calculating the germination rate index (GRI) using a modified Timson index of germination velocity $=\Sigma G / t$, where " $G$ " is the percentage of seed germination at two days intervals, and " $\mathrm{t}$ " is the total germination period [4]. The germination rate was only calculated for seeds incubated under light conditions.

Three-way ANOVA (Analyses of Variance) was used to determine the effects of the three factors (storage condition, and light and temperature of incubation) and their interactions on final germination. Two-way ANOVA was used to assess the impact of storage condition and incubation temperature and their interactions on GRI. Tukey HSD test was used for multiple comparisons to determine significant differences among the treatments at $P=0.05$. The germination percentages were arcsine-transformed and germination rate was log-transformed before statistical analysis to normalize the variance. All statistical analyses were performed using SYSTAT, version 13.0.

\section{Results}

\section{Germination traits of seeds without pretreatment by $\mathrm{NaOCl}$}

There were significant effects $(P<0.05)$ of storage condition, and incubation temperature and light on the final germination of $C$. prophetarum seeds (Table 1 ). The gemination had a negative relationship with incubation temperature $\left(15 / 25^{\circ} \mathrm{C}\right.$ : $34.3 \%, 20 / 30^{\circ} \mathrm{C}$ : $33.5 \%$ and $\left.25 / 35^{\circ} \mathrm{C}: 28.7 \%\right)$. The seed germination was significantly greater in light (42.7\%) than in dark (21.7\%). For storage conditions, the overall germination of both fresh and freeze stored seeds ( $58.7 \%$ and $58.2 \%$, respectively) was significantly greater than seeds stored in the field and room temperature (6.7 and $5.1 \%$, respectively).

There were significant effects of interactions between storage conditions and light of incubation on the final germination of $C$. prophetarum seeds $(P<0.001$, Table 1$)$. In all the four storage conditions, the final 
germination was significantly higher in light than dark. The germination of freeze stored seeds at $20 / 30^{\circ} \mathrm{C}$ was higher than at $25 / 35^{\circ} \mathrm{C}$ and $15 / 25^{\circ} \mathrm{C}$, while germination at $15 / 25^{\circ} \mathrm{C}$ was the highest in fresh seeds (Fig. 1).

Table 1

Results of three-way ANOVA showing the effects of seed storage condition and temperature and light of incubation on final germination of Cucumis prophetarum for non-treated seeds. Ns, not significant at P $\geq 0.05$.

\begin{tabular}{|lllll|}
\hline Source & df & Mean Squares & F-Ratio & p-Value \\
\hline Storage condition (S) & 3 & 2.195 & 134.826 & $<0.001$ \\
\hline Temperature (T) & 2 & 0.057 & 3.473 & $<0.05$ \\
\hline Light (L) & 1 & 1.363 & 83.686 & $<0.001$ \\
\hline S*T & 6 & 0.033 & 2.05 & Ns \\
\hline S*L & 3 & 0.301 & 18.507 & $<0.001$ \\
\hline T*L & 2 & 0.036 & 2.196 & Ns \\
\hline S*T*L & 6 & 0.024 & 1.489 & Ns \\
\hline Error & 48 & 0.016 & & \\
\hline
\end{tabular}

In light, seed germination at $20 / 30^{\circ} \mathrm{C}$ was significantly greater than at $25 / 35^{\circ} \mathrm{C}$ and $15 / 25^{\circ} \mathrm{C}$ for fresh and freeze stored seeds while there was little difference between the three temperatures for the field and room temperature stored seeds. In the dark, conversely, the germination of fresh seeds at $15 / 25^{\circ} \mathrm{C}$ was significantly greater than at $25 / 35^{\circ} \mathrm{C}$ and $20 / 30^{\circ} \mathrm{C}$, respectively. However, there was no germination for room temperature stored seeds at $25 / 35^{\circ} \mathrm{C}$ temperature regime (Fig. 1).

The germination speed of room temperature stored seeds was lowest than the other three storage conditions (Figs. 2 and 3).

\section{Effect the sterilization by $\mathrm{NaOCl}$ on seed germination}

There were significant effects of sterilization by $\mathrm{NaOCl}$ on seed germination of $C$. prophetarum $(\mathrm{P}<$ $0.001)$. The pretreatment of seeds by $\mathrm{NaOCl}$ resulted in reduced germination speed and percentage (Fig. 1). The germination percentage of seeds without and with sterilization were $(32.2 \%$ and $17.6 \%$, respectively), and the germination speed was 39.3 and 26.6, respectively. In all storage conditions, the final germination of non-sterilized seeds was higher than seeds treated by $\mathrm{NaOCl}$ except for the frozen seeds in light and at $15 / 25^{\circ} \mathrm{C}$ as there were small differences between them (Fig. 1). For germination speed, seeds without sterilization were faster than sterilized except for fresh seeds, where there was no significant difference recorded (Figs. 2 and 3). 
For seeds with pretreatment by $\mathrm{NaOCl}$, there were significant effects $(\mathrm{P}<0.001)$ of storage condition, light and temperature of incubation, and their interaction $(P<0.01)$ on the final germination (Table 2$)$.

The sterilized seeds had the same trend as non-sterilized seeds; fresh seeds had the highest germination, followed by freeze, field, and room temperature stored seeds (35.6\%, 29.3\%, 4.9\%, and $0.7 \%$, respectively). Also, germination at lower temperature (i.e., $15 / 25^{\circ} \mathrm{C}$ ) was higher than $20 / 30^{\circ} \mathrm{C}$ and $25 / 35^{\circ} \mathrm{C}(23.2 \%$, $19.7 \%$, and $10.0 \%$, respectively). Overall, more seeds germinated in light $(27.2 \%)$ than in the dark (8.0\%).

Table 2

Results of three-way ANOVA showing the effects of seed storage condition and temperature and light of incubation on final germination of Cucumis prophetarum for seeds pretreated using $\mathrm{NaOCl}$.

\begin{tabular}{|lllll|}
\hline Source & df & Mean Squares & F-Ratio & p-Value \\
\hline Storage condition (S) & 3 & 0.636 & 82.336 & $<0.001$ \\
\hline Temperature $(\mathrm{T})$ & 2 & 0.145 & 18.819 & $<0.001$ \\
\hline Light $(\mathrm{L})$ & 1 & 0.838 & 108.392 & $<0.001$ \\
\hline $\mathrm{S} * \mathrm{~T}$ & 6 & 0.073 & 9.393 & $<0.001$ \\
\hline $\mathrm{S} * \mathrm{~L}$ & 3 & 0.337 & 43.613 & $<0.001$ \\
$\mathrm{~T} * \mathrm{~L}$ & 2 & 0.051 & 6.614 & $<0.01$ \\
\hline $\mathrm{S} * \mathrm{~T} * \mathrm{~L}$ & 6 & 0.077 & 9.956 & $<0.001$ \\
\hline Error & 48 & 0.008 & & \\
\hline
\end{tabular}

Unlike untreated seeds, the overall germination of $\mathrm{NaOCl}$ treated freeze stored seeds was greater at $15 / 25^{\circ} \mathrm{C}$ than in other temperatures. Also, in both dark and light incubation, the seed germination was highest at $15 / 25^{\circ} \mathrm{C}$ than the other temperatures in freeze storage seeds (Fig. 1).

In the field stored seeds, the germination was faster at $20 / 30^{\circ} \mathrm{C}$ than the other two temperatures tested. The germination speed was very slow at $15 / 25^{\circ} \mathrm{C}$ in the room temperature stored seeds (Fig. 2). The germination speed in the light was lower in both field and room temperature storage seeds compared with the other two storage conditions (Fig. 3).

\section{Discussion}

The germination capacity and longevity of seed under different environmental conditions are considered critical factors for understanding the ecological dynamics of a plant species. The seed storage behavior has an important association with plant ecology [55]. According to this hypothesis, orthodox species might be originating from occasional or seasonal drought environments in which the desiccation tolerance of seeds is essential for seed survival and seedling establishment [56]. Seeds of most plants inhabiting arid and desert regions have an orthodox storage behavior [56, 8, 31]. Many studies reported 
that viability of the orthodox seeds after freezing is not different from the original state $[11,57,58]$. In our study, seeds of $C$. prophetarum had good germination at the time of dispersal (i.e., fresh seeds), as about $58.6 \%$ of the seeds succeed in germinating at different temperatures and light conditions of incubation. This case did not differ almost for dried, and one-year freeze stored seeds; the germination was approximately $58.2 \%$. Consequently, the storage behavior of $C$. prophetarum seeds can be classified as orthodox, and as a result, they can be stored under conventional seed banking conditions.

Achigan-Dako et al. (59) reported that stored seeds of $C$. lanatus subsp mucosospermus Fursa, Cucumeropsis mannii Naud. and Lagenaria siceraria (Molina) Standl. with moisture contents ranged from $4-10 \%$ at $25^{\circ} \mathrm{C}$ maintained their ability to germinate after 60 days. Also, seeds of $C$. lanatus germinated well after storage between $40^{\circ} \mathrm{C}$ and $55^{\circ} \mathrm{C}$ with moisture contents ranging from $4-10 \%$. Other studies documented that stored seeds ( 2 to 12 months storage) of $C$. lanatus can give good germination with 3.6-9\% moisture contents and temperatures between $20-40^{\circ} \mathrm{C}[60,61]$. In the present study, the germination of fresh and freeze stored seeds of $C$. prophetarum was high and almost identical. In contrast, germination of field and room temperature stored seeds was low. The lower germination of field and room temperature stored seeds may be due to their long-time storage in high humidity (above $35 \%$ ) with higher (more than 10\%) seed moisture contents.

Temperature and light form the main ecological factors in regulating seed germination $[19,18,62]$. Many studies have reported the critical role of incubation light and temperatures on seed germination of Cucurbitaceae species. The present study showed that the seeds of $C$. prophetarum germinated well in low and moderate temperatures $\left(15 / 25\right.$ and $\left.20 / 30^{\circ} \mathrm{C}\right)$ than higher temperature regime $\left(25 / 35^{\circ} \mathrm{C}\right)$. These results are incompatible with previous studies on Cucurbitaceae species as their seeds required high temperatures for greater germination and exhibited poor germination at low temperatures $[54,63,4]$. For example, in certain melon varieties, a combination of lower seed coat permeability for oxygen and hypoxia of embryo were considered the main factors that might have caused poor germination at low temperature [64]. But our results are consistent with the study of Saberali \& Shirmohamadi-Aliakbarkhani [65], where the best seed germination percentage of Cucumis melo L. was at $15^{\circ} \mathrm{C}$ to $25^{\circ} \mathrm{C}$, and any increase in temperature after this range will lead to a decrease of seed germination.

The seed coat of Cucumis species is thinner than some of the Cucurbitaceae species, such as Citrullus species. Therefore, the seed coat of $C$. prophetarum, perhaps, is no obstacle for the diffusion of the oxygen and the water required for germination. In addition, the ability of $C$. prophetarum seeds to germinate in tested temperatures is probably correlated with the temperature range that the plant experience in the natural habitat as it grows mostly in mountain regions which have a lower temperature than the other desert habitats in UAE.

Seeds of many Cucurbitaceae species have negative photoblastic behavior, whereas their germination is better in the dark than in light, as reported in C. lanatus, ucurbita maxima, L. siceraria, Benincasa hispida and Momordica harantia [53], C. lanatus var. citroides [66] and $C$. colocynthis [4, 67]. Our results did not agree with these patterns where the seed germination percentage of $C$. prophetarum was almost double 
in light than in the dark. Species that require light for germination have seeds surrounding them maternal tissues that contain chlorophyll, which reduces the R: FR ratio in the seeds throughout maturation and consequently needs light for germination $[68,69,67]$.

The $C$. prophetarum plants have green dense and large leaves during their growth stages, and fruits remain attached with the parent plant partially under the canopy until dispersal time. In addition, the fruits are green at the younger stage then convert to yellow color when starting to ripe. Therefore, a large amount of chlorophyll can reduce R: FR ratio in the seeds, and consequently, they need light for germination [see 67]. These plants thrive in mountain areas, and their seeds may fall deep between the rocks that limit seedling emergence. Still, the seeds might have adapted their position in the soil surface to ensure the continuity of plant growth after germination.

Although the germination percentage of fresh and freeze storage seeds was very close in the present study, it varied under the tested temperature regime. The highest germination of freeze stored seeds was at $20 / 30^{\circ} \mathrm{C}$, while for fresh seeds, it was highest at $15 / 25^{\circ} \mathrm{C}$. This difference is probably due to the effects of the light condition on the germination at these temperatures. In the dark, the fresh seeds had the highest germination at $15 / 25^{\circ} \mathrm{C}$, but the freeze stored seeds had the highest germination at $20 / 30^{\circ} \mathrm{C}$ (Fig. 1). El-Keblawy et al. [4] supposed that the storage did not affect seed viability but might have changed phytochrome sensitivity in the dark $[68,70]$.

In the present study, the purpose of using the $\mathrm{NaOCl}$ prior to the germination process of $C$. prophetarum was to sterilize seeds against bacteria, viruses, and fungi. For ensuring the validity of the results and the sterilization did not adversely affect the seed germination experiment outcome, we performed an additional experiment without seed sterilization (control). As we expected, the treatment of the seeds by $\mathrm{NaOCl}$ adversely affected the germination of $C$. prophetarum seeds. We recorded a considerable decrease in germination of seeds from all storage conditions and under light and temperature of incubation.

It has been reported that the treatment of seeds by $\mathrm{NaOCl}$ can cause changes in seed metabolism that influence the seed germination process $[71,72]$. $\mathrm{NaOCl}$ has been reported to promote, inhibit and be ineffective at the seed germination stage in different species $[73,74,75,76]$. These varying results may be caused by the differences in treatment duration and $\mathrm{NaOCl}$ concentrations used $[77,78]$. $\mathrm{NaOCl}$ was an effective treatment for stimulating germination or breaking dormancy in some species, such as $P$. convolvulus and $S$. vaccaria [38]. For these species, $\mathrm{NaOCl}$ might have increased the permeability of the seed coat to oxygen and loss of germination inhibitors [39, 36]. Also, Wenny and Dumroese [79] reported that sterilizing conifer seeds with $\mathrm{NaOCl}$ resulted in increased germination percentage, which was probably due to reduced fungal infection [42]. Yildiz \& $\mathrm{Er}$ [34] linked the mechanism of $\mathrm{NaOCl}$ action to induce seed germination and partial degradation of the seed coat.

However, for the same species ( $P$. convolvulus and $S$. vaccaria), long-duration treatment by $\mathrm{NaOCl}$ reduces germination of seeds [38,36]. On the other hand, Hsiao [38] supposed that $\mathrm{NaOCl}$ treatment of seeds for a longer duration than the optimum result in a decrease of germination due to disintegration of the seed or the effect of $\mathrm{NaOCl}$ on seed biochemical and metabolism processes. Ditommaso \& Nurse [37] 
indicated that the concentration and exposure time of $\mathrm{NaOCl}$ could affect seed germination. For example, the germination of $A$. powellii seeds increased when soaked in $6 \% \mathrm{NaOCl}$ for less than 60 seconds but started to decline as treatment duration increases [37]. For Linum usitatissimum L., higher concentrations of disinfectant reduced the germination of its seeds, where the best germination was obtained at $40 \%$ concentration of $\mathrm{NaOCl}$ [34]. According to Akbari et al. [42], the treatment of seeds by $2 \% \mathrm{NaOCl}$ could increase the germination percentage of Oryza sativa $\mathrm{L}$. and increasing the concentration leads to a decrease in the germination. Moreover, Hsiao \& Quick [80] reported that the seed germination of Avena fatua L. decreased when seeds were treated with more than optimal concentration of $\mathrm{NaOCl}$, which could lead to damage to some of the seeds beyond their capacity to repair.

We can deduce from the previous studies that germination of $\mathrm{NaOCl}$ sterilized seeds of $C$. prophetarum, which have no hard coats, was decreased due to an increase in the concentration of the solution than the optimum limit, and perhaps reducing the concentration of $\mathrm{NaOCl}$ leads to increases in the germination. Secondly, the long exposure time of $\mathrm{NaOCl}$ and probably reducing the exposure time may leads towards maintaining or increasing the germination percentage.

Interestingly, in our study, the germination of sterilized freeze stored seeds of $C$. prophetarum increased at low temperature than untreated seeds. Though the interpretation of this result still unclear but perhaps the combination of freeze condition "low-temperature" and the light of incubation has an effect of $\mathrm{NaOCl}$ efficiency on seed germination.

Only sterilized fresh seeds of $C$. prophetarum, despite the decrease of their germination, had the same trend of germination of non-sterilized seeds in light and temperature conditions (Fig. 1). Also, similar germination speed for both the sterilized and non-sterilized fresh seeds remains unclear and require further study.

\section{Conclusion}

Our results confirm that $C$. prophetarum seeds have an orthodox seed storage behavior and can be dried without losing viability. The overall results indicate that the seed germination of $C$. prophetarum is sensitive to seed storage conditions and light and temperature of incubation and the sterilization of seeds by $\mathrm{NaOCl}$. The germination results of $C$. prophetarum was incompatible with many studies of Cucurbitaceae species as it was higher in light than dark and low and moderate temperature than high temperature. Regarding the negative effect of $\mathrm{NaOCL}$ on the germination traits of $C$. prophetarum, we recommend a priori test for a small number of seeds with a diluted $\mathrm{NaOCl}$ concentration (i.e., $0.6 \%$ or lower) within a short exposure time (i.e., 30 seconds) to determine optimal concentrations and exposure periods for species having similar seed coat characteristics. Our results highlight the importance of understanding the germination traits of $C$. prophetarum in arid environments. However, further research is required to understand the seed biology and germination physiology of $C$. prophetarum.

\section{Abbreviations}


GRI

Germination rate index

$\mathrm{NaOCl}$

Sodium hypochlorite

\section{Declarations}

\section{Acknowledgements}

The authors would like to thank Prof. Amr Abdel-Hamid, Director General of Sharjah Research Academy, for encouragement and support. The authors extend their gratitude to Mrs. Ghada Sakr for her assistance in formatting this manuscript, Mr. Mohamed Fiaz and Mr. Mohamed Abo Al Nour for their assistance in fieldwork. Ms. Reena Cordeiro helped in linguistic revision of the manuscript, we thank her.

\section{Authors' contributions}

All authors read and approved the final manuscript. HS conceived the idea and performed the data analyses. HS, TM, and SG collected the seeds, designed the research and wrote the manuscript. AA, MA1, MA2 conducted the lab work, and contributed in writing the manuscript.

\section{Funding}

This research did not receive any specific grant from funding agencies in the public, commercial, or notfor-profit sectors.

\section{Availability of data and materials}

Seeds used in this study and the datasets are available from the corresponding author on request.

\section{Ethics approval and consent to participate}

In this study, all seeds were collected under international standard seed bank guidelines for scientific research. The permission was not needed to collect such samples for research purposes. We confirm that this study did not involve endangered or protected species. The voucher specimens (SSBH 1237 \& SSBH 1255) were deposited in the herbarium of SSBH, Sharjah, UAE.

\section{Consent for publication}

Not applicable.

\section{Competing Interests}

The authors declare that they have no conflict of interest.

\section{Publisher's Note}


Springer Nature remains neutral with regard to jurisdictional claims in published maps and institutional affiliations.

\section{References}

1. Roach DA, Wulff RD. Maternal effects in plants. ANNU REV ECOL SYST. 1987;18(1):209-35.

2. El-Keblawy AA, Bhatt A. Aerial seed bank affects germination in two small-seeded halophytes in Arab Gulf desert. J. Arid Environ. 2015;117:10-17.

3. Gorecki MJ, Long RL, Flematti GR, Stevens JC. Parental environment changes the dormancy state and karrikinolide response of Brassica tournefortii seeds. ANN BOT-LONDON. 2012;109(7):1369-78.

4. El-Keblawy A, Shabana HA, Navarro T, Soliman S. Effect of maturation time on dormancy and germination of Citrullus colocynthis (Cucurbitaceae) seeds from the Arabian hyper-arid deserts. BMC Plant Biol. 2017;17(1):263.

5. Bhatt A, Phondani PC, Pompelli MF. Seed maturation time influences the germination requirements of perennial grasses in desert climate of Arabian Gulf. Saudi Journal of Biological Sciences. 2018;25(8):1562-67.

6. El-Keblawy A, Shabana HA, Navarro T. Seed mass and germination traits relationships among different plant growth forms with aerial seed bank in the sub-tropical arid Arabian deserts. Plant Ecol Divers. 2018;11(3):393-404.

7. Ellis RH, Hong TD, Roberts EH. An intermediate category of seed storage behaviour? I. Coffee. J. Exp. Bot. 1990;41(9):1167-74.

8. Hong TD, Linington S, Ellis RH. Seed storage behaviour: a compendium. Handbook for Genebanks. No. 4. Rome: International Plant Genetic Resources Institute; 1996.

9. Tweddle JC, Dickie JB, Baskin CC, Baskin JM. Ecological aspects of seed desiccation sensitivity. J. Ecol. 2003;91(2):294-304.

10. Ajayi SA, Berjak P, Kioko JI, Dulloo ME, Vodouhe RS. Responses of fluted pumpkin (Telfairia occidentalis Hook. f.; Cucurbitaceae) seeds to desiccation, chilling and hydrated storage. S. Afr. J. Bot. 2006;72(4):544-50.

11. Roberts EH. Predicting the storage life of seeds. Seed Sci. Technol. 1973;1:499-514.

12. Walters C, Berjak P, Pammenter N, Kennedy K, Raven P. Preservation of recalcitrant seeds. Science. 2013;339(6122):915-16.

13. Weston LA, Geneve RL, Staub JE. Seed dormancy in Cucumis sativus var. hardwickii (Royle) Alef. Sci Hort. 1992;50(1-2):35-46.

14. Baskin CC, Baskin JM. Seeds: ecology, biogeography, and evolution of dormancy and germination. USA, San Diego: Elsevier; 2014.

15. Willis CG, Baskin CC, Baskin JM, Auld JR, Venable DL, Cavender-Bares J, Donohue K, Rubio de Casas $\mathrm{R}$, Group NEGW. The evolution of seed dormancy: environmental cues, evolutionary hubs, and diversification of the seed plants. New Phytol. 2014;203:300-09. 
16. Koornneef M, Bentsink L, Hilhorst H. Seed dormancy and germination. Curr. Opin. Plant Biol. 2002;5(1):33-36. https://doi.org/10.1016/S1369-5266(01)00219-9.

17. Chauhan BS, Johnson DE. Influence of environmental factors on seed germination and seedling emergence of eclipta (Eclipta prostrata) in a tropical environment. WEED SCI. 2008;383-88.

18. Chen Y, Cao Q, Li D, Liu H, Zhang D. Effects of temperature and light on seed germination of ephemeral plants in the Gurbantunggut Desert, China: implications for vegetation restoration. J. Arid Land. 2019;11(6):916-27.

19. Bewley JD, Bradford K, Hilhorst H. Seeds: physiology of development, germination and dormancy. Springer Science \& Business Media; 2012.

20. Tanveer A, Salman Arshad M, Ayub M, Mansoor Javaid M, Yaseen M. Effect of temperature, light, salinity, drought stress and seeding depth on germination of Cucumis melo var. agrestis. . 2012;18(4).

21. Gunster A. Aerial seed banks in the central Namib: distribution of serotinous plants in relation to climate and habitat. J. Biogeogr. 1992;19(5):563-72. https://doi.org/10.2307/2845775.

22. Thanos CA. Bradychory - The coining of a new term. In: Arianoutsou M, Papanastis VP, editors. Proceedings 10th Medecos Conference. Rotterdam, Rhodes: Millpress; 2004. p.1-6.

23. Shabana HA. Plant dispersal strategies of different ecological desert habitats of United Arab Emirates. Doctoral thesis. Spain: University of Malaga; 2019:181.

24. Lamont BB. Canopy seed storage and release: what's in a name? Oikos. 1991;60(2):266-8. https://doi.org/10.2307/3544876.

25. Gutterman Y, Ginott S. Long-term protected 'seed bank' in dry inflorescences of Asteriscus pygmaeus; achene dispersal mechanism and germination. J. Arid Environ. 1994;26(2):149-63. https://doi.org/10.1006/jare.1994.1019.

26. Gao R, Yang X, Yang F, Wei L, Huang Z, Walck JL. Aerial and soil seed banks enable populations of an annual species to cope with an unpredictable dune ecosystem. Ann. Bot. 2014;114(2):279-87. https://doi.org/10.1093/aob/mcu104.

27. Martínez-Berdeja A, Ezcurra E, Sanders AC. Delayed seed dispersal in California deserts. Madroño. 2015;62(1):21-32. https://doi.org/10.3120/0024-9637-62.1.21.

28. Roberts EH. Seed ageing-the genome and its expression. In: Nooden LD, Leopold AC, editors. Senescence and Ageing in Plants. New York: Academic Press; 1988. p. 465-598.

29. Parmar YS. Effect of seed storage conditions on seed germination and vigor of Withania somnifera. Int. J. Pharmacogn. Phytochem. 2018;7(6): 1409-13.

30. Bewley JD, Black M. Seeds: Physiology of development and germination. New York: Plenum Press;1994.

31. Thompson K. The functional ecology of soil seed banks. In: Fenner M, editor. Seeds: The Ecology of Regeneration in Plant Communities, 2nd edn. Oxford: CAB International; 2000. p. 215-35. 
32. Allan A. Plant cell culture. In: Stafford A, Warren G, editors. Plant cell and tissue culture. Milton Keynes: Open University Press; 1991. p. 1-24.

33. Ervin GN, Wetzel RG. Effects of sodium hypochlorite sterilization and dry cold storage on germination of Juncus effusus L. Wetlands. 2002;22(1):191-95.

34. Yildiz M, Er C. The effect of sodium hypochlorite solutions on in vitro seedling growth and shoot regeneration of flax (Linum usitatissimum). Sci. Nat. 2002;89(6):259-61.

35. Abdul-Baki AA. Pitfalls in using sodium hypochlorite as a seed disinfectant in $14 \mathrm{C}$ incorporation studies. Plant Physiol. 1974;53(5):768-71.

36. Hsiao Al. The effect of sodium hypochlorite and gibberellic acid on seed dormancy and germination of wild oats (Avena fatua). Can J Bot. 1979a;57(16):1729-34.

37. Ditommaso A, Nurse RE. Impact of sodium hypochlorite concentration and exposure period on germination and radicle elongation of three annual weed species. Seed Sci. Technol. 2004;32(2):37791.

38. Hsiao Al. The effect of sodium hypochlorite, gibberellic acid, and light on seed dormancy and germination of wild buckwheat (Polygonum convolvulus) and cow cockle (Saponaria vaccaria). Can J Bot. 1979b;57(16):1735-39.

39. Frank AB, Larson KL. Influence of Oxygen, Sodium Hypochlorite, and Dehulling on Germination of Green Needlegrass Seed (Stipa viridula Trin.) 1. Crop Sci. 1970;10(6):679-82.

40. Butola JS, Badola HK. Use of Sodium hypochlorite to enhance seedling emergence, vigor, and survival of Angelica glauca and Aconitum heterophyllum. J Herbs Spices Med Plants. 2008;13(4):110.

41. Ferreira WR, Ranal MA. Seed germination and seedling growth of Brassica chinensis L. var. parachinensis (Bailey) Sinskaja (flowering white cabbage). Pesqui. Agropecu. Bras. 1999;34:353-61.

42. Akbari M, Akbari M, Akbari D, Sajedi NA. Influence of sodium hypochlorite on seed germination and early seedling growth of rice (Oryza sativa L.) variety Tarum. Research on Crops. 2012;13(1):11-15.

43. Renner SS, Schaefer H. Phylogeny and evolution of Cucurbitaceae. In: Grumet R, Katzir N, GarciaMas J, editors. Genetics and genomics of Cucurbitaceae. Cham, Switzerland: Springer International; 2016. p. 13-23.

44. Rai M, Pandey S, Kumar S. Cucurbit research in India: a retrospect. In: Pitrat M, editor. Proceedings of the IXth EUCARPIA meeting on genetics and breeding of Cucurbitaceae, INRA. France: Avignon; 2008. p. 285-94.

45. Khidr Y, Nasr M. Improvement of genetic transformation and plant regeneration via suspension cultures in Cucurbitaceae family. EJGC. 2012;41(1):1-18.

46. Avinash T, RavishankarRai V. Identification of diverse fungi related with selected Cucurbitaceae vegetables. Journal of Agricultural Technology. 2013;9(7):1837-48.

47. Sadou H, Sabo H, Alma MM, Saadou M, Leger CL. Chemical content of the seeds and physicochemical characteristic of the seed oils from Citrullus colocynthis, Coccinia grandis, Cucumis 
metuliferus and Cucumis prophetarum of Niger. Bull Chem Soc Ethiop. 2007;21(3):323-30.

48. Kavishankar GB, Lakshmidevi N. Anti-diabetic effect of a novel N-Trisaccharide isolated from Cucumis prophetarum on streptozotocin-nicotinamide induced type 2 diabetic rats. Phytomedicine. 2014;21(5):624-30.

49. Jongbloed $M$. The comprehensive guide to the wild flowers of the United Arab Emirates. UAE, Abu Dhabi: Environmental Research and Wildlife Development Agency; 2003.

50. Karim FM, Fawzi NM. Flora of the United Arab Emirates, Volume 1. UAE, Al Ain: United Arab Emirates University; 2007.

51. van Oudtshoorn KVR, van Rooyen MW. Dispersal biology of desert. Adaptations of desert organisms. New York, Berlin: Heidelberg, Springer; 1999.

52. Shabana HA, Navarro T, El-Keblawy A. Dispersal traits in the hyper-arid hot desert of the United Arab Emirates. Plant Ecology and Evolution. 2018;151(2):194-208. https://doi.org/10.5091/plecevo.2018.1359.

53. Nakamura S, Okasako Y, Yamada E. Effect of light on the germination of vegetable seeds. Journal of the Japanese Society for Horticultural Science. 1955;24(1):17-28. http://doi.org/10.2503/jjshs.24.17.

54. Edelstein M, Kigel J. Seed germination of melon (Cucumis melo) at sub-and supra-optimal temperatures. Scientia Horticulturae. 1990;45(1):55-63. https://doi.org/10.1016/03044238(90)90068-P.

55. Roberts EH, King MW. The characteristics of recalcitrant seeds. In: Chin HF, Roberts EH, editors. Recalcitrant Crop Seeds. Malaysia, Kuala Lumpur: Tropical Press; 1980. p. 1-5.

56. Hong TD, Ellis RH. A protocol to determine seed storage behaviour, IPGRI Technical Bulletin No. 1. Italy, Rome: International Plant Genetic Resources Institute; 1996.

57. Ibrahim AE, Roberts EH. Viability of lettuce seeds: I. Survival in hermetic storage. Journal of Experimental Botany. 1983;34(5):620-30.

58. Hong TD, Ellis RH. The survival of germinating orthodox seeds after desiccation and hermetic storage. Journal of Experimental Botany. 1992;43(2):239-47.

59. Achigan-Dako EG, Avohou HT, Ahouanmagnagahou RA, Vodouhe RS, Ahanchede A. Viability response of cucurbit seeds (Citrullus lanatus subsp. mucosospermus, Cucumeropsis mannii and Lagenaria siceraria) stored under various moisture content and temperature conditions. Seed Science and Technology. 2009;37(2):520-26.

60. Demir I, van de Venter H. Survival of Watermelon (Citrullus lanatus (Thunb.) Matsum. And Nakai) seeds at $40^{\circ} \mathrm{C}$ prolonged by prior storage at $30^{\circ} \mathrm{C}$. Seed Science Research. 1999;9:259-61. doi:10.1017/S0960258599000264.

61. Vodouhe SR, Achigan-Dako GE, Dulloo ME, Kouke A. Effects of silica gel, sun drying and storage conditions on viability of Egusi seed (Curcubitaceae). Plant Genetic Resources Newsletter. 2008;153:36-42. 
62. Guo C, Shen Y, Shi F. Effect of Temperature, Light, and Storage Time on the Seed Germination of Pinus bungeana Zucc. ex Endl.: The Role of Seed-Covering Layers and Abscisic Acid Changes. Forests. 2020;11(3):300.

63. Edelstein M, Bradford KJ, Burger DW. Metabolic heat and CO2 production rates during germination of melon (Cucumis melo L.) seeds measured by microcalorimetry. Seed Science Research. 2001;11(3):265-72. https://doi.org/10.1079/SSR200182.

64. Edelstein M, Corbineau E, Kigel J, Nerson H. Seed coat structure and oxygen availability control low temperature germination in melon (Cucumis melo) seeds. Physiologia Plantarum. 1995;93(3):45156. https://doi.org/10.1111/j.1399-3054.1995.tb06842.x.

65. Saberali SF, Shirmohamadi-Aliakbarkhani Z. Quantifying seed germination response of melon (Cucumis melo L.) to temperature and water potential: Thermal time, hydrotime and hydrothermal time models. South African Journal of Botany. 2020;130:240-49.

66. Ramirez AHM, Jhala AJ, Singh M. Factors affecting germination of citronmelon (Citrullus lanatus var. citroides). Weed science. 2014;62(1):45-50. https://doi.org/10.1614/WS-D-13-00041.1.

67. El-Keblawy A, Soliman S, Al-Khoury R, Ghauri A, Al Rammah H, Hussain SE, Rashid S, Manzoor Z. Effect of maturation conditions on light and temperature requirements during seed germination of Citrullus colocynthis from the Arabian Desert. Plant Biology. 2019;21(2):292-99.

68. Cresswell EG, Grime JP. Induction of a light requirement during seed development and its ecological consequences. Nature. 1981;291:583-85.

69. Dechaine JM, Gardner G, Weinig C. Phytochromes differentially regulate seed germination responses to light quality and temperature cues during seed maturation. Plant, Cell and Environment. 2009;32:1297-309.

70. Casal JJ, Sánchez RA. Phytochromes and seed germination. Seed Science Research. 1998;8:317-29.

71. Thomas TH. Seed treatments and techniques to improve germination. Scientific Horticulture. 1981;32:47-59.

72. Mahajan G, Mutti NK, Jha P, Walsh M, Chauhan BS. Evaluation of dormancy breaking methods for enhanced germination in four biotypes of Brassica tournefortii. Scientific reports. 2018;8(1):1-8.

73. Ilahi I, Hussain F. Germination improvement of Reptonia buxifolia (Falc.) A. DC., with physicochemical factors. Pakistan J. Forest. 1988;38:69-78.

74. Vujanovic V, St-Arnaud M, Barabé D, Thibeault G. Viability testing of orchid seed and the promotion of colouration and germination. ANN BOT-LONDON. 2000;86(1):79-86.

75. Nwangburuka CC, Oyekale K, Ezekiel CN, Anokwuru PC, Badaru O. Effects of Moringa oleifera leaf extract and sodium hypochlorite seed pre-treatment on seed germination, seedling growth rate and fungal abundance in two accessions of Abelmoschus esculentus (L) Moench. Archives of Applied Science Research. 2012;4(2):875-81.

76. Varasteh KN, Babaei A, Abdoli M. The effect of different sodium hypochlorite concentrations on seed germination of Dracocephalum moldavica L. Austin J. Plant Biol. 2015;1:1007-10. 
77. Mendes de Jesus VA, Araujo EF, Neves AA, Santos FL, Dias LAS, Ferreira da Silva R. Ratio of seeds and sodium hypochlorite solution on the germination process of papaya seeds. J. Seed Sci. 2016;38:57-61.

78. Çavuşoğlu KÜRŞAT, Doğu FADIME, Çavuşoğlu DILEK. Effects of sodium hypochlorite on some physiological and cytogenetical parameters in Allium cepa L. exposed to salt stress. Bangladesh J Bot. 2019;48:223-29.

79. Wenny DL, Dumroese RK. Germination of conifer seeds surface sterilized with bleach. Tree planters' notes. 1987;38(3):18-21.

80. Hsiao Al, Quick WA. Actions of sodium hypochlorite and hydrogen peroxide on seed dormancy and germination of wild oats, Avena fatua L. Weed Research. 1984;24(6):411-19.

81. Böer B. An introduction to the climate of the United Arab Emirates. J Arid Environ. 1997;35(1):3-16.

82. Sherif M, Akram S, Shetty A. Rainfall analysis for the northern wadis of United Arab Emirates: A case study. Journal of Hydrologic Engineering. 2009;14(6):535-44.

https://doi.org/10.1061/(ASCE)HE.1943-5584.0000015.

83. Merabtene T, Siddique M, Shanableh A. Assessment of seasonal and annual rainfall trends and variability in Sharjah City, UAE. ADV METEOROL. 2016;2016:1-13. http://dx.doi.org/10.1155/2016/6206238.

\section{Figures}



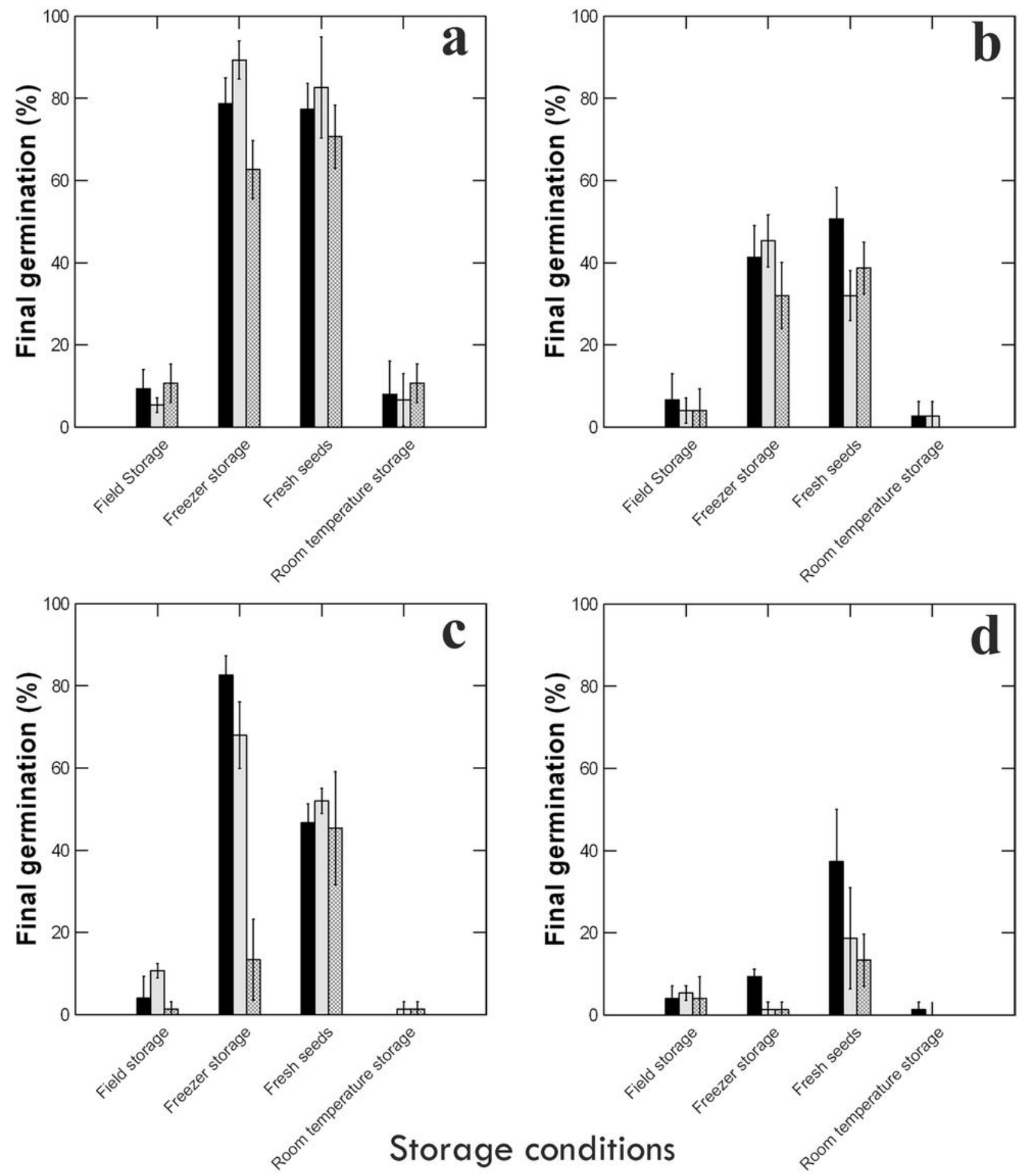

$15 / 25^{\circ} \mathrm{C} \square 20 / 30{ }^{\circ} \mathrm{C} 25 / 35^{\circ} \mathrm{C}$

\section{Figure 1}

Effect of seed storage condition and incubation temperature on final germination (mean \pm SE) of Cucumis prophetarum seeds. Non-treated seeds (a) light and (b) dark, and pretreated seeds by $\mathrm{NaOCl}(\mathrm{c})$ light and (d) dark. 




$15 / 25^{\circ} \mathrm{C} \square 20 / 30{ }^{\circ} \mathrm{C} 225 / 35{ }^{\circ} \mathrm{C}$

Figure 2

Effect of seed storage condition and temperature of incubation on germination rate index (mean $\pm \mathrm{SE}$ ) of Cucumis prophetarum seeds. (a) Non-treated seeds and (b) pretreated by $\mathrm{NaOCl}$. 


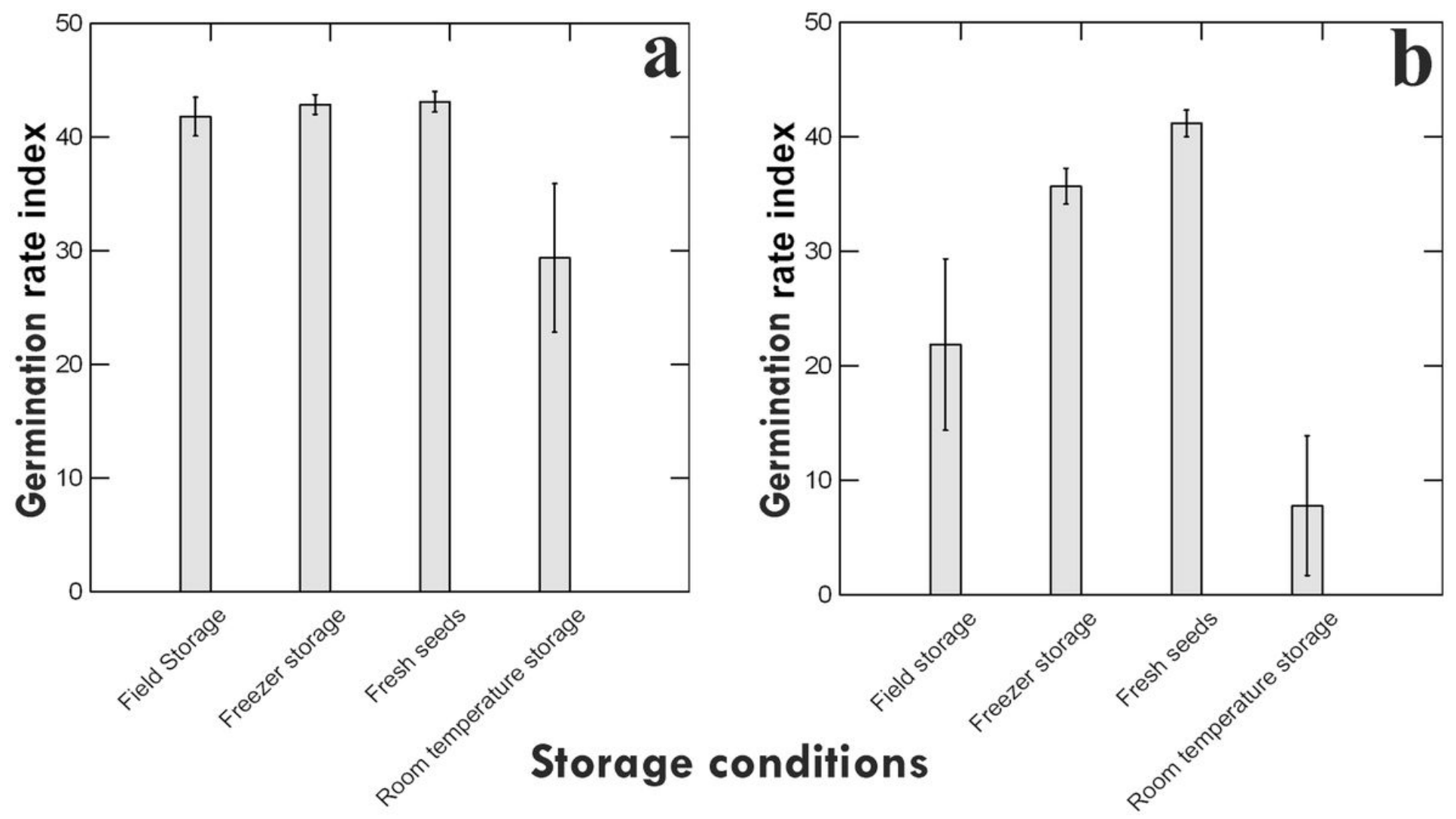

Figure 3

Effect of seed storage condition on germination rate index (mean \pm SE) of Cucumis prophetarum seeds.

(a) Non-treated seeds and (b) pretreated by $\mathrm{NaOCl}$. 